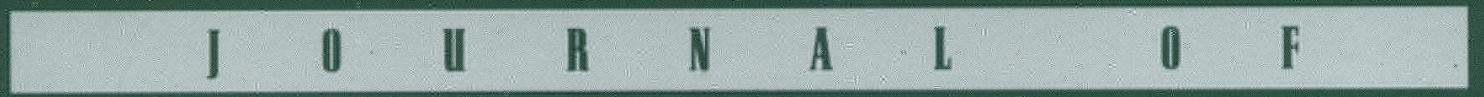

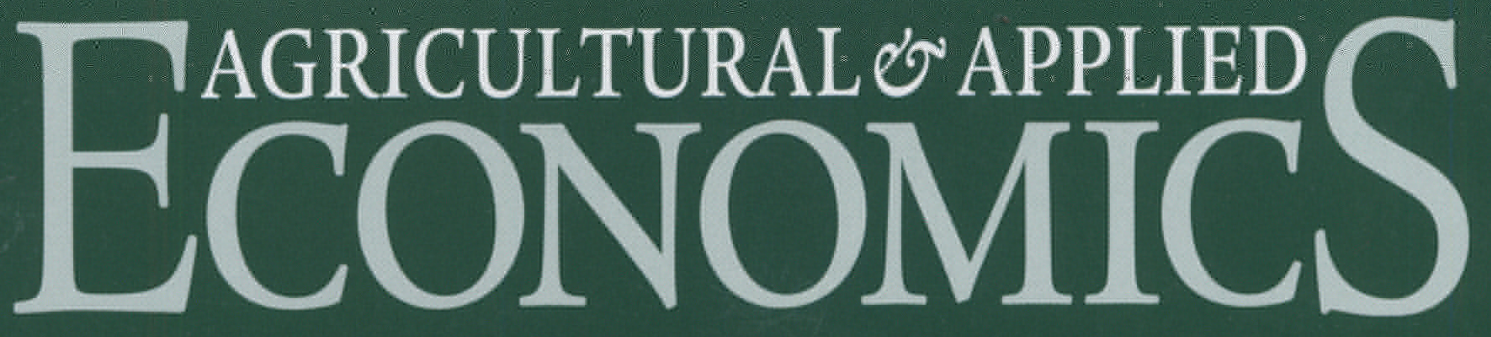

\title{
VIILINIE 43
}

Viay 2UlII

VIIMBEER 2

Disentangling Access and View Amenities in Access-Restricted Coastal Residential Communities / O. Ashton Morgan and Stuart E. Hamilton

An Evaluation of Factors Affecting the Choice of Coastal Recreational Activities / Krishna P. Paudel, Rex H. Caffey, and Nirmala Devkota

Crop Supply Response under Risk: Impacts of Emerging Issues on Southeastern U.S. Agriculture / Yan Liang, J. Corey Miller; Ardian Harri, and Keith H. Coble

Crop Insurance, Disaster Payments, and Land Use Change: The Effect of Sodsaver on Incentives for Grassland Conversion / Roger Claassen, Joseph C. Cooper, and Fernando Carriazo

The Effect of Social Capital on the-Choice to Use Sustainable Agricultural Practices / Abdul B.A. Munasib and Jeffrey L. Jordan

Impact of Mandatory Price Reporting on Hog Market Integration / Jason R.V. Franken, Joe L. Parcell, and Glynn T. Tonsor

Assessing Consumer Willingness to Pay for Value-Added Blueberry

Products Using a Payment Card Survey / Wuyang Hu, Timothy Woods, Sandra Bastin, Linda Cox, and Wen You

Will Changing Demographics Affect U.S. Cheese Demand? /

Christopher G. Davis, Donald Blayney, Diansheng Dong, Steven T. Yen, and Rachel J. Johnson 


\section{EDITORIAL STAFF}

Editors

\author{
Jeffrey Gillespie \\ Louisiana State University \\ Ashok Mishra \\ Louisiana State University
}

\author{
Mary A. Marchant \\ Virginia Tech \\ Darrell J. Bosch \\ Virginia Tech
}

Associate Editor

Michael Wetzstein

University of Georgia

Editorial Council

Giovanni Anania
University of Calabria, Italy
Jean Paul Chavas
University of Wisconsin-Màdison
Patricia Duffy
Auburn University
Barry K. Goodwin
North Carolina State University
R. Wes Harrison
Louisiana State University
Jeffrey L. Jordan
University of Georgia
Catherine Kling
Iowa State University
Carl Johan Lagerkvist
Swedish University of Agricultural Sciences
William Liefert
Economic Research Service, USDA

Giovanni Anania

Jean Paul Chavas

Jayson Lusk

Oklahoma State University

Kenneth Matthews, Jr.

Economic Research Service, USDA

Gopinath Munisamy

Oregon State University

David Pannell

University of Western Australia

James W. Richardson

Texas A\&M University

Jutta Roosen

Technische Universitaet Muenchen

Jason Shogren

University of Wyoming

Dawn Thilmany

Colorado State University

\section{EDITORIAL POLICY}

The Journal of Agricultural and Applied Economics (JAAE) provides a forum for creative and scholarly work in agricultural economics and related areas. Contributions on methodology and applications in business, extension, research, and teaching phases of agricultural and applied economics are equally encouraged. Submitted manuscripts are subject to peer review for publication consideration. Submission of critiques or comments on JAAE articles are welcomed.

\section{EDITORIAL COMMUNICATIONS}

Please address editorial correspondence to one of the following co-editors: Darrell Bosch, Department of Agricultural and Applied Economics, Virginia Tech, Blacksburg, VA 24061 (Phone: 540-231-5265, Fax: 540-231-7417, E-mail: bosch@vt.edu) or Mary Marchant, Department of Agricultural and Applied Economics, Virginia Tech, Blacksburg, VA 24061 (Phone: 540-231-1674, Fax: $340-231-7417$, E-matl mary marchanfat vedu). Manuscripts should be submitted on-1ine following the instructions given on the inside back cover of this volume.

The Journal of Agricultural and Applied Economics (ISSN 1074-0708) is published in February, May, August, and November by the Southern Agricultural Economics Association (SAEA). Visit our worldwide wob site at http:/www.agecon.uga.edu/ jaae/jaachtrn.

Copyright 2011 by the Southern Agricultural Economics Association. Any article or other material published in the $J A A E$ may not be resubmitted for publication or republished elsewhere in full or in part without the written permission of the editor. 

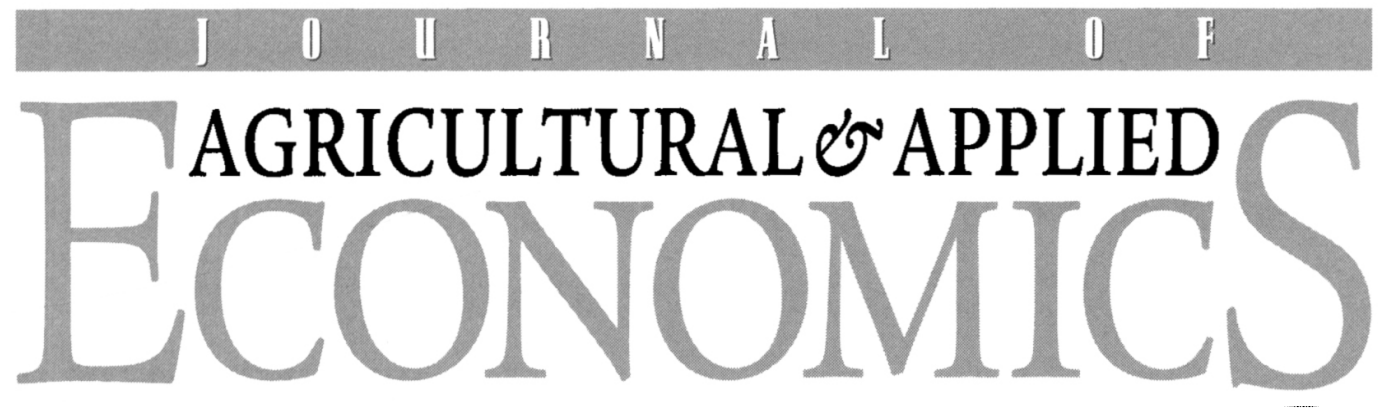

VOLIIME 43

MAY 2OII

NIIMBER 2

Disentangling Access and View Amenities in Access-Restricted Coastal Residential Communities / O. Ashton Morgan and Stuart E. Hamilton . . . . . . . . . . . . . . . . . . 157

An Evaluation of Factors Affecting the Choice of Coastal Recreational Activities /

Krishna P. Paudel, Rex H. Caffey, and Nirmala Devkota . . . . . . . . . . . . . . . .

Crop Supply Response under Risk: Impacts of Emerging Issues on Southeastern U.S. Agriculture / Yan Liang, J. Corey Miller, Ardian Harri, and Keith H. Coble . . . . . . . . . . . . . . .

Crop Insurance, Disaster Payments, and Land Use Change: The Effect of Sodsaver on Incentives for Grassland Conversion / Roger Claassen, Joseph C. Cooper, and Fernando Carriazo . . . .

The Effect of Social Capital on the Choice to Use Sustainable Agricultural Practices /

Abdul B.A. Munasib and Jeffrey L. Jordan. . . . . . . . . . . . . . . . . . . . . . . . . .

Impact of Mandatory Price Reporting on Hog Market Integration / Jason R.V. Franken,

Joe L. Parcell, and Glynn T. Tonsor. . . . . . . . . . . . . . . . . . . . . . . . . . . . . .

Assessing Consumer Willingness to Pay for Value-Added Blueberry Products Using a Payment

Card Survey / Wuyang Hu, Timothy Woods, Sandra Bastin, Linda Cox, and Wen You . . . . . .

Will Changing Demographics Affect U.S. Cheese Demand? / Christopher G. Davis,

Donald Blayney, Diansheng Dong, Steven T. Yen, and Rachel J. Johnson 